\title{
A Complete Review for Metacognitive, Cognitive, and Social/Affective Strategies as Essential Components of Learning strategies and their relationships with EFL Learners' Reading Comprehension Promotion
}

\author{
Mahdiyeh Seyed Beheshti Nasab \\ Tabriz University of Medical Sciences, Tabriz, Iran \\ E-mail: bns.violet@gmail.com
}

\author{
Seyyed Fariborz Pishdadi Motlagh (Corresponding author) \\ Department of Foreign Languages and Literature, University of Tabriz, Tabriz, Iran \\ E-mail: Fpishdadi@yahoo.com
}

\author{
Doi:10.7575/aiac.alls.v.6n.3p.166 \\ URL: http://dx.doi.org/10.7575/aiac.alls.v.6n.3p.166
}

Received: 13/02/2014

Accepted: 18/04/2015

\begin{abstract}
This study attempts to shed light on how learners' exact attention can be in line with learning meaningfully and bring about remarkable changes in the learning ability of upper-intermediate EFL learners through employing certain learning strategy items with the aim of enhancing reading scores and consequently injecting into learners a sense of satisfaction with their work. Additionally, this study aimed to investigate the relationship of metacognitive, cognitive, and social/affective strategies with EFL learners' reading comprehension. To this end, the study employed a quasiexperimental design with a placement test as a proficiency test to find the homogeneity of groups. Each group received one main strategy and then, according to Oxford (1990) training model, the students were exposed to those strategies accompanied with reading comprehension texts. Learners' progress and also the relationship of those strategies with reading comprehension were measured during the sixteen sessions of teaching and employing the strategies. Independent sample T-Test with Pearson correlations indicated that metacognitive group significantly outperformed the other groups, so metacognitive strategies were more in line with EFL learners' reading comprehension.
\end{abstract}

Keywords: Learning strategy, Metacognitive, Cognitive, Social/Affective strategy, Reading comprehension

\section{Introduction}

Recently educational psychologists pay more attention to the term metacognition, because it is important in learning and is a strong predictor in promoting L2 learners' reading comprehension. Metacognition refers to the ability to reflect upon, understand, and control one's own learning (Schraw \& Denisson, 1994; Living stone, 1997). According to Akin, Abaci and Cetin, (2007), the term metacognition is an extremely important concept, affecting individual learning process. As Flavell (1979) remarks, metacognition relates to the phenomena of what we do and how we learn. Individual's metacognitive awareness is regarded as a prominent factor in enhancing their learning through their life, critical thinking and self-confidence (Memnuu \& Akkaya, 2009). Chastain (1998) believes that one of the main difficulties which all learners come across during their L2 skills' progression is finding how and what to do in order to be a better and developed learner. It is a challenging task for teachers to help these unsuccessful students to solve learning problems (p. 204). Metacognitive awareness relates to our ability of thinking and develops and uses practical problem-solving skills to overcome learning difficulties (Joseph, 2010).

Garner and Alexander (1989) investigated that learners with high metacognitive awareness are better than unaware learners. Always successful learners have a wide variety of thinking skills. They know about their own knowledge and know when, where and how to apply it to different learning situations. Schraw and Denisson (1994) believe that with metacognitive awareness individuals can plan, sequence and monitor their learning in a way that directly improves performance. They find that learners with high metacognition can monitor and direct their own learning process; they can direct information, and apply the learning strategies to solve the problems. Students with high metacognition can explain better academic performance, also people with poor and low metacognition are believed incompetent as they perform inadequately relative to their peers. Poor metacognition has a deep relationship with ineffective learning strategies. Success of human activities is determined by a number of variables, one of them is individual's learning strategies. Smith and Colb (1996) declared that a person's learning strategy describes her/his behavior in different daily situations. Learners learn more effectively, easily and comfortably when their learning needs are generated by their learning experience. Learning strategy shows the way a person learns. Also learning strategy is linked with the way a person processes and perceives information in learning situations. Learning a second language involves learning of four main skills, speaking, and writing, listening and reading which lead to effective communication. Teachers have tried 
activities which are effective for teaching the four skills. Study of teaching techniques is very popular among teachers. However a study of students themselves has not had much focus yet. Studying metacognitive strategies is an undertaking which focuses more on students themselves. The present study, therefore, found replies those calls for an empirical search for a pedagogical model designed to enhance learners' metacognitive awareness and learning strategy use when engaging in $\mathrm{L} 2$ reading practice.

\subsection{Research Questions}

1- Is there any significant relationship between metacognitive strategies and EFL learners' reading comprehension in terms of their reading promotion?

2- Is there any significant relationship between cognitive strategies and EFL learners' reading comprehension in terms of their reading promotion?

3- Is there any significant relationship between social/affective strategies and EFL learners' reading comprehension in terms of their reading promotion?

\section{Review of the Related Literature}

Flavell (1976) believed that metacognition is one's knowledge concerning one's own cognitive processes and put or anything related to them, also described about metacognition which includes the active monitoring and consequent regulation and orchestration of information processing activities. According to Baird (1990) using these ideas to provide the following succinct formulation: "Metacognition refers to the knowledge, awareness and control of one's own learning" (p.184). Based on the ideas of (Kuhn, 2000, p. 178) metacognition refers to two aspects, learner's selfawareness of a knowledge based that saves the information about how, when, and where to use various cognitive strategies and their self-awareness of and access to strategies that direct learning (e.g. monitoring difficulty level, a feeling of knowing).

Anderson (2002) believed that metacognition is thinking about thinking. The use of metacognitive strategies can lead to higher learning and better performance teachers can help L2 learners by understanding and controlling cognitive processes. At first all researches about metacognition were descriptive and explained conscious and deliberate storage and retrieval of information of children's knowledge about memory processes. However as studies moved from descriptive to empirical, the kinds of methodology expanded. Regarding metacognition, despite of important differences among several methods, there were three general categories: cognitive monitoring, cognitive regulation and a combination of both. Skilled readers use one or more metacognitive strategies to comprehend texts. According to Pintrich, Wolters, and Baxter (2000), there are three main aspects of metacognition: metacognitive knowledge, metacognitive monitoring, self-regulation and control. The first group consists of cognitive learning strategies which the learner uses to regulate the process of knowledge acquisition. These include, for example, elaboration strategies such as the building of links to prior knowledge, or memory strategies such as note taking. The second group consists of metacognitive control strategies. Fundamental points here are activities like the planning and monitoring of learning activities, the evaluation of learning outcomes and the adaptation to varying task demands and (unexpected) difficulties, for example, an increase in directed efforts. In addition to these two groups, which are dominant in research and crucial for the learning process, a third group of strategies in the model developed by Pintrich and Garcia (1994) is devoted to resource management. These strategies are concerned with the control of the general conditions associated with learning, for example, time management and management of the learning environment.

Metacognition turns to the ability to reflect upon, understand, and control one's learning. There are two types of metacognition that have distinguished between two main components, including knowledge about cognition and regulation of cognition (Brown, 1987; Flavell, 1987; Jacobs \& Paris, 1987). Knowledge about cognition includes three sub processes that make easy the reflective aspect of metacognition: declarative knowledge (i.e., knowledge about self and about strategies), procedural knowledge (i.e. knowledge about how to use strategies), and conditional knowledge (i.e. knowledge about when and why to use strategies). Regulation of cognition encompasses a number of sub processes that accelerate the control aspect of learning. Five component skills of regulation have been scrutinized extensively, including planning, information management strategies, comprehension monitoring, debugging strategies, and evaluation (Artzt \& Armour-Thomas, 1992; Baker, 1989).

\subsection{A framework for understanding metacognition}

According to Garner (1987) most of the researchers agree that cognition and metacognition differ in that cognitive skills are necessary to perform a task, while metacognition is necessary to understand how the task was performed. Majority of the researchers also make a distinction between two components of metacognition, knowledge of cognition and regulation of cognition. Flavell (1987) describes that Knowledge of cognition refers to what individuals know about their own cognition or about cognition in general. It includes at least three distinct types of metacognitive awareness: declarative, procedural, and conditional knowledge (Brown, 1987; Jacobs \& Paris, 1987). There are exact descriptions such as: Declarative knowledge refers to knowing about things. Procedural knowledge refers to knowing how to do things. Conditional knowledge refers to knowing the why and when aspects of cognition. As Baker (1989) mentioned that declarative knowledge includes knowledge about oneself as a learner and about what factors influence one's performance. For example, research examining what learners know about their own memory indicates that adults have more knowledge than children about the cognitive processes connected with memory. Similarly, as (Garner, 1987; Schneider \& Pressley, 1989) believe, good learners appear to have more knowledge about different aspects of memory 
such as capacity limitations, rehearsal, and distributed learning. Procedural knowledge refers to knowledge about doing things. Much of this knowledge is represented as heuristics and strategies.

\subsection{Promoting metacognitive awareness}

Schraw (1998) illustrated that metacognition differs from cognition; it is multidimensional, and domain-general in nature. The main part of his argument shows that metacognition fills a unique niche in the self-regulatory phylum, by providing domain-general knowledge and regulatory skills that enable individuals to control cognition in multiple domains. Metacognition is flexible and indispensable in his view. There are four general ways to increase metacognition in classroom settings (Hartman \& Sternberg, 1993). These include promoting general awareness of the importance of metacognition, improving knowledge of cognition, improving regulation of cognition, and fostering environments that promote metacognitive awareness.

\subsection{Promoting general awareness}

Students need to understand the distinction between cognition and metacognition to become self-regulated. Teachers, other students, and reflection each play an important role in this process. Teachers model both cognitive and metacognitive skills for their students. The more explicit this modeling, the more likely it is that students will develop cognitive and metacognitive skills (Butler \& Winne, 1995). Other students provide effective models as well, and in many situations, are better models than teachers (Schunk, 1989). Frequently, students are better able to model cognitive and metacognitive skills, and provide a powerful rationale for these skills within the student's zone of proximal development, compared to teachers. Extended practice and reflection play crucial roles in the construction of metacognitive knowledge and regulatory skills. This is especially true when students are given regular opportunities to reflect on one's successes and failures (Kuhn, Schauble \& Garcia-Mila, 1992; Siegler \& Jenkins, 1989). Studies examining the construction of theories of mind also suggest that reflection, both as a solitary and group endeavor, contributes to the breadth and sophistication of such theories (Astington, 1993; Montgomery, 1992).

\subsection{Reading and Metacognition}

Researchers such as (Bazerman 1985; Pressley \& Afflerbach 1995) mentioned that some studies on reading strategies about what expert readers do manifest in order to successful comprehension does not occur automatically. Rather, it depends on directed cognitive effort, referred to as metacognitive processing which consists of knowledge about and regulation of cognitive processing. Alexander \& Jetton (2000) supported that the idea of during reading metacognitive processing is expressed through strategies, which are "procedural, purposeful, effortful, willful, essential, and facilitative in nature" (p. 295). Reader must purposefully or intentionally implement strategies, also modulate and enhance learning from text. Through metacognitive strategies, a reader allocates significant attention to controlling, monitoring, and evaluating the reading process (Pressley 2000; Pressley, Brown, El-Dinary, \& Afflerbach 1995).

Some researchers (Taraban, R. Kerr, M, and Rynearson, K, 2004) identified 14 strategies from the data that was used by which called tactics. These were separated into three types, by consensus. One type was text-noting tactics, and included highlighting, underlining, circling, copying key words, phrases or sentences, paraphrasing in notes, outlining and diagramming. The second type was mental- learning tactics and included rote learning of specific information, mental integration, relating information to background knowledge, imaging, visualizing, self-questioning and selftesting. The third type was reading tactics, which included reading only, skimming, reading slowly, and re-reading selected text. These data reveal that reading strategies are directed toward comprehension, but also toward studying and remembering. Poor readers are less aware of effective strategies and of the counterproductive effects of poor strategies, and are less effective in their monitoring activities during reading.

\subsection{The Relationship between Cognitive and Metacognitive strategies}

Glenberg (2005) identified that Metacognition or metacognitive knowledge is clarified as knowledge of the mental processes which are involved in different kinds of learning. Metacognition has two basic aspects: knowledge about cognition and self-directed thinking. Self-directed thinking is conducted by evaluation, planning, and regulation activities (Metacognition involves active monitoring and consequent regulation and orchestration of cognitive processes to achieve cognitive goals). Flavell (1971) illustrated completely about metacognition and it is intentional, planned, purposeful, goal-directed and future-oriented mental processing that can be used to fulfill cognitive tasks. Richards \& Schmidt (2002) found that always learners are competent of becoming aware of their own mental processes. This includes recognizing which kinds of learning tasks cause difficulty, which approaches to remembering information work better than others and how to solve different kinds of problems. Metacognitive knowledge is thought to impact the kinds of learning strategies learners choose. In order for people to use metacognition to enhance their learning, they need to be aware of their own learning tendencies and be willing to be introspective (Lipson \& Wixson, 1983; Bokowski, Carr, Rellinger \& Pressley, 1990; Paris, White, 1998). Siegler (1990) mentioned that through being ready to consider conditional aspects such as when it is appropriate to use particular strategies, it is more likely that students will develop abilities to evaluate, self-direct and self-regulate their learning (Boekaerts, 1997). Different studies have demonstrated that learning can be enhanced if students use metacognitive processes; that is, if they are aware of monitor and controls their own learning (Baird, 1998; Hacker, 1998). Generally speaking, good learners have been shown to be metacognitive talented and poor ones metacognitive flawed in how they tackle learning tasks in most subjects (Baird, 1998; Conner, 2006). 
Contrary to traditional cognitive views, current views on reading development recognize the relevance of socioaffective factors. Anderson (1999) includes that building motivation in his strategies for teaching second language reading. Greaney (1996) argued for reading instruction to focus more on instilling joy and pleasure in learners than on teaching cognitive skills. Verhoeven and Snow (2001, P.2) neither argue that, without some level of motivation, neither orthographic knowledge nor comprehension strategies are likely to develop optimally. They further argue that the notion of engagement in literacy requires redefining literacy itself to acknowledge the degree to which it is a social activity and an affective commitment, in addition to being a cognitive accomplishment (as cited in Boakye, 2011, p.115). Serpell \& Street, (2001); Niven, (2005) all agree to the influence of social factors in reading development, and argue for socio-cultural assurances to literacy development. Bus (2001) highlighted the social aspect of reading development strongly in his study and found that the interactive experience that children receive from their parents affects the frequency and quality of parent-child book reading and, consequently, the development of literacy.

\section{Method}

\subsection{Design of the study}

In this quasi-experimental study, a proficiency test was employed to make clear that all of the students in the three groups are homogenous and are in the same level. After administrating the proficiency test, three experimental classes which lasted for 8 weeks were given treatments with metacognitive, cognitive, and social/affective strategies in classes. Then, the groups received three comprehensible reading passages appropriate to their level of proficiency selected from Longman TOEFL test, which were taught and exposed during course and presented to the learners with metacognitive, cognitive, and social/affective strategies instructions. Every session, students were made familiar with some of the subcategories of each strategy according to the Oxford's (1990) training model and it was clearly obvious that some strategies were paid more attention by learners. For example, monitoring, planning, evaluating in metacognitive, note taking, summarizing, translating, repeating in cognitive, relaxation, rewarding, discussing feelings with others in affective and asking for correction, cooperating with others, becoming aware of others' feelings in social strategies, were paid more attention compared to other items. These findings were more important and understandable. So, learners tended to apply them because of their comprehensiveness and learners' interest in some special strategies. Having answered the required tests and questions, the elicited data statistically were analyzed and interpreted. At the end of the course, the results of the experimental groups were compared and the effects of the training were manifested.

\subsection{Participants}

A total of 90 language learners (females and males) with the age range of 16-26 participated in this study. The participants were chosen from upper intermediate classes out of 130 learners. At first, before the beginning of the study, a proficiency test was employed to find out that whether these learners are homogeneous or not. Then, the researcher administrated the study in three experimental classes containing 30 participants in each class. Next, each class received some noticeable instruction of three basic items of learning strategies according to Brown (2000) taxonomy (cognitive, metacognitive, and social/affective strategies), in order to improve learners awareness and thinking about their understanding, and consequently enhancing their competence and performance. After that, as a matter of test reliability and validity, a TOEFL test was used. Furthermore, to be assured that the items were fitted appropriately to the participants' level of proficiency, three comprehensible reading passages extracted from TOEFL books were taught in the three experimental groups.

\subsection{Materials}

Basically, a standard placement test by Oxford University and Cambridge University (2001) was administrated as a proficiency test. Furthermore, related to test reliability and validity, Longman TOEFL test was used and all items were fitted appropriately to the participants' level of proficiency, so three comprehensible reading passages were extracted from Longman Complete Course for the TOEFL Test by Deborah Phillips (2001). Besides, the researcher evaluated the three main learning strategies (metacognitive, cognitive, and social/affective) in order to find out which strategy far overweighed the other ones.

\subsection{Procedures}

After administering the placement test, the treatment sessions involving teaching and explaining of, cognitive, metacognitive, and socio-affective strategies that each one has some significant and prominent branches were discussed and elaborated during sixteen sessions and accordingly, three reading passages proper to participants' level with 50 multiple choice questions accompanied with every learning strategy, were started and evaluated. During the treatment period, inspired by Oxford's (1990) training model, the teacher provided three main strategies in details, especially the most significant ones related to each main strategy. As mentioned earlier, monitoring, planning, evaluating in metacognitive, note taking, summarizing, translating, repeating in cognitive, relaxation, rewarding, discussing feelings with others in affective and asking for correction, cooperating with others, becoming aware of others feelings in social strategies were more tangible and comprehensible for learners because it was clear that learners were more enthusiastic to know about items which were familiar for them and consequently tried to employ some items more than other ones. Then, in order to measure effects of the three different types of learning strategies in promoting EFL learners reading comprehension, the descriptive statistics including mean scores, standard deviation; for each group's accurate use of the cognitive, metacognitive, and social/affective strategy was presented and illustrated in the tables of descriptive statistics clearly. 
The participants in all three experimental groups participated in sixteen sessions of strategy training. Each session the participants made familiar with certain items, at the end of treatment the reading passages distributed to learners in order to respond to the tests by employing the determined strategies for each group. The steps taken during the strategy instruction period was as follows: The concept of learning strategies was explained and then, different kinds of strategies involving the main ones according to Brown (2000) taxonomy (cognitive, metacognitive, and social/affective) were briefly described. However, the concentration was on metacognitive awareness, so the metacognitive reading strategies were described completely. The main metacognitive processes which were discussed were planning, monitoring and evaluation. The teacher asked students to do the followings: To think about the passage's topic; to consider about what they know, what links they can make, and what questions they may answered; to suppose about how text features can help in understanding the title; to think about the way the text might be organized.

The monitoring engaged the learners' minds before and during teaching. Also besides, according to O'Malley and Chamot (1985, cited in Brown, 2000, p.125), self-monitoring is the process of "correcting one's speech for accuracy in pronunciation, grammar, vocabulary, or for being suitable and related to the setting to the people who are present". Therefore, the instructor encouraged the learners to use their findings in texts; to monitor their comprehension by themselves (self-monitoring) through thinking aloud, that is to reflect and explain what was happening in their minds through engaging with the problem; to ask them "Do I get what I just read? Or what does the author actually want me to know about this text?"

To connect, to predict, to infer, to use context clues, to use text features, and to find text structures.

Furthermore, the evaluating was done during and after teaching in the following manner: Students evaluate their findings (self-evaluating); Students ask themselves how well did I understand? What strategies worked well for me? For instance, thinking before teaching, monitoring and thinking aloud or evaluating the findings after teaching the main points, and etc.

What strategies did not work well for me?

Do I need some help for the next time?

This evaluative component of the metacognitive process was so valuable (noted in Brown, 2000, p.125).

The present study aimed to certify the relationships of cognitive, metacognitive, and social/affective strategies with EFL learners' reading comprehension and to show which strategy is the most influencing factor. By applying these strategies, researcher wants to find the significance of using cognitive, metacognitive, and social/affective strategies among students and to infer that which one is more important than the other. Having discussed, applied, and evaluated the method; the following statistical procedures were used. Data were analyzed through applying Statistical Package for the Social Sciences (SPSS) based on Windows Version 11.0. A homogenous test, an independent t-test, Pearson correlations were applied at the .05 level of significance to answer research question. Descriptive statistics (frequency, mean, and standard deviations) were used to examine the overall strategy use, by taking Brown's (2000) three classifications. In this research, three taxonomies were used as independent variables, whereas reading comprehension was regarded as dependent variable.

\section{Data Analysis and Results}

Table 1. Descriptive statistics of metacognitive, cognitive, and social/affective strategy groups' homogeneity

score-hemogenous
\begin{tabular}{|l|r|r|r|r|}
\hline & $\mathrm{N}$ & Mean & Std. Deviation & Std. Error \\
\hline metacognitive & 30 & 32.5000 & 6.42060 & 1.17224 \\
cognitive & 30 & 25.3667 & 5.51164 & 1.00628 \\
social/affective & 30 & 30.7333 & 5.22549 & .95404 \\
Total & 90 & 29.5333 & 6.44458 & .67932 \\
\hline
\end{tabular}

Table 1 demonstrates the homogeneity of all the three groups. The results are expressed as mean $\pm \mathrm{SD}(\mathrm{N}=90$ ). According to the descriptive findings of the quasi-experiment, the first variable is the metacognitive strategy of the learners $(32.50 \pm 6.42)$. Additionally, the second variable is cognitive strategy of the participants $(25.36 \pm 5.51)$. Furthermore, this table indicates social/affective strategy of the learners with a mean of 30.73, and standard deviation of 5.22, respectively. Also, as we discussed earlier, this table shows that the range of scores are between 20-40 in a 60 item placement test, so the mean of the scores emphasize that groups are in the correct order and they have been distributed well. Also, as mentioned before, all the learners are in the upper intermediate level (range of scores is mostly 30-40) and subjects are homogeneous.

Table 2. Distribution of learners' sex in cognitive group

\begin{tabular}{|ll|r|r|r|r|}
\hline & & & & \multicolumn{1}{c|}{$\begin{array}{c}\text { Cumulative } \\
\text { Percent }\end{array}$} \\
\hline Valid & girl & 14 & 46.7 & 46.7 & 46.7 \\
& boy & 16 & 53.3 & 53.3 & 100.0 \\
& Total & 30 & 100.0 & 100.0 & \\
\hline
\end{tabular}




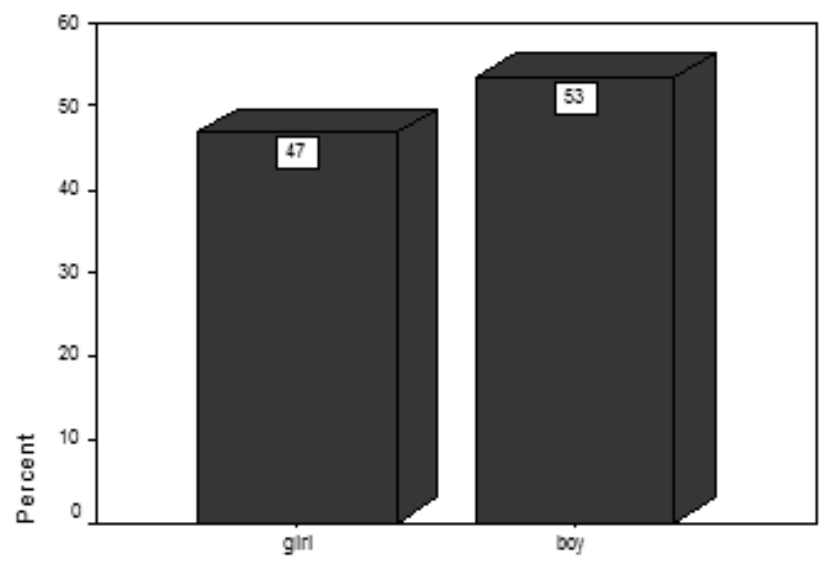

Figure 1. Histogram of learners' sex in cognitive group

Table 3. Distribution of learners' age in cognitive group

\begin{tabular}{|c|c|c|}
\hline N & $\begin{array}{l}\text { Valid } \\
\text { Missing }\end{array}$ & $\begin{array}{r}30 \\
0\end{array}$ \\
\hline \multicolumn{2}{|c|}{ Mean } & 19.1667 \\
\hline \multicolumn{2}{|c|}{ Std. Deviation } & 4.15297 \\
\hline \multicolumn{2}{|c|}{ Skewness } & .508 \\
\hline \multicolumn{2}{|c|}{ Std. Error of Skewness } & .427 \\
\hline \multicolumn{2}{|c|}{ Range } & 10.00 \\
\hline \multicolumn{2}{|c|}{ Minimum } & 15.00 \\
\hline \multicolumn{2}{|c|}{ Maximum } & 25.00 \\
\hline
\end{tabular}

Table 4. Distribution of learners' age in cognitive group

\begin{tabular}{|rr|r|r|r|r|}
\hline & & Frequency & Percent & Valid Percent & $\begin{array}{c}\text { Cumulative } \\
\text { Percent }\end{array}$ \\
\hline Valid & 15.00 & 8 & 26.7 & 26.7 & 26.7 \\
& 16.00 & 4 & 13.3 & 13.3 & 40.0 \\
17.00 & 3 & 10.0 & 10.0 & 50.0 \\
18.00 & 2 & 6.7 & 6.7 & 56.7 \\
19.00 & 2 & 6.7 & 6.7 & 63.3 \\
20.00 & 1 & 3.3 & 3.3 & 66.7 \\
22.00 & 1 & 3.3 & 3.3 & 70.0 \\
24.00 & 1 & 3.3 & 3.3 & 73.3 \\
25.00 & 8 & 26.7 & 26.7 & 100.0 \\
\hline Total & 30 & 100.0 & 100.0 & \\
\hline
\end{tabular}

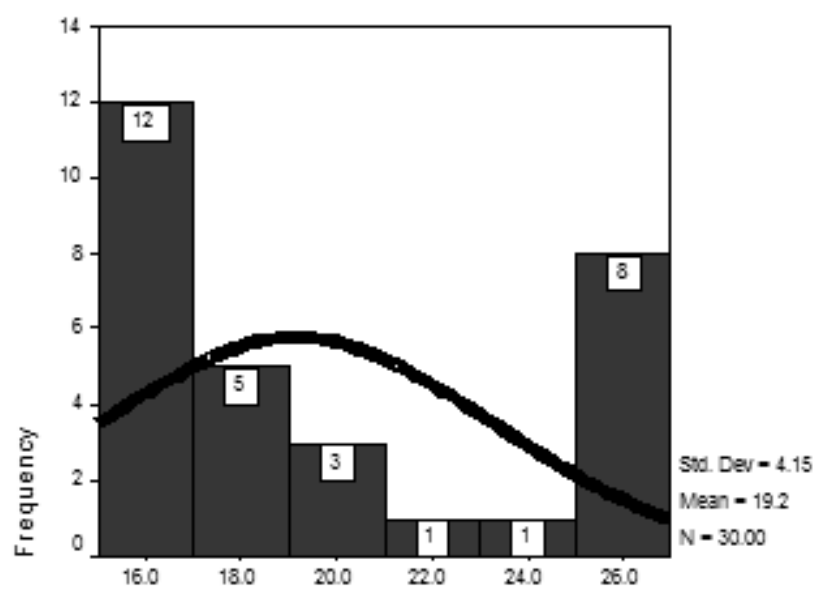

Figure 2. Histogram of learners' age in cognitive group 
Table 5. Distribution of learners' scores in cognitive group

\begin{tabular}{|c|c|c|}
\hline $\mathrm{N}$ & $\begin{array}{l}\text { Valid } \\
\text { Missing }\end{array}$ & $\begin{array}{r}30 \\
0\end{array}$ \\
\hline \multicolumn{2}{|c|}{ Mean } & 24.7667 \\
\hline \multicolumn{2}{|c|}{ Std. Deviation } & 14.42145 \\
\hline \multicolumn{2}{|c|}{ Skewness } & .686 \\
\hline \multicolumn{2}{|c|}{ Std. Error of Skewness } & .427 \\
\hline \multicolumn{2}{|c|}{ Range } & 44.00 \\
\hline \multicolumn{2}{|c|}{ Minimum } & 6.00 \\
\hline \multicolumn{2}{|c|}{ Maximum } & 50.00 \\
\hline
\end{tabular}

According to table 5 reading scores' mean in cognitive group is 24.76 with the standard deviation of 14.42 and skewness of .686, it is obvious that minimum of reading scores is 6 and maximum number is 50 .

Table 6. Frequency of learners' scores in cognitive group

\begin{tabular}{|c|c|c|c|c|c|}
\hline & & Frequency & Percent & Valid Percent & $\begin{array}{c}\text { Cumulative } \\
\text { Percent }\end{array}$ \\
\hline \multirow[t]{20}{*}{ Valid } & 6.00 & 1 & 3.3 & 3.3 & 3.3 \\
\hline & 9.00 & 1 & 3.3 & 3.3 & 6.7 \\
\hline & 10.00 & 1 & 3.3 & 3.3 & 10.0 \\
\hline & 11.00 & 2 & 6.7 & 6.7 & 16.7 \\
\hline & 12.00 & 3 & 10.0 & 10.0 & 26.7 \\
\hline & 15.00 & 3 & 10.0 & 10.0 & 36.7 \\
\hline & 16.00 & 2 & 6.7 & 6.7 & 43.3 \\
\hline & 18.00 & 1 & 3.3 & 3.3 & 46.7 \\
\hline & 19.00 & 1 & 3.3 & 3.3 & 50.0 \\
\hline & 23.00 & 2 & 6.7 & 6.7 & 56.7 \\
\hline & 24.00 & 3 & 10.0 & 10.0 & 66.7 \\
\hline & 30.00 & 2 & 6.7 & 6.7 & 73.3 \\
\hline & 35.00 & 1 & 3.3 & 3.3 & 76.7 \\
\hline & 45.00 & 1 & 3.3 & 3.3 & 80.0 \\
\hline & 46.00 & 1 & 3.3 & 3.3 & 83.3 \\
\hline & 47.00 & 1 & 3.3 & 3.3 & 86.7 \\
\hline & 48.00 & 2 & 6.7 & 6.7 & 93.3 \\
\hline & 49.00 & 1 & 3.3 & 3.3 & 96.7 \\
\hline & 50.00 & 1 & 3.3 & 3.3 & 100.0 \\
\hline & Total & 30 & 100.0 & 100.0 & \\
\hline
\end{tabular}

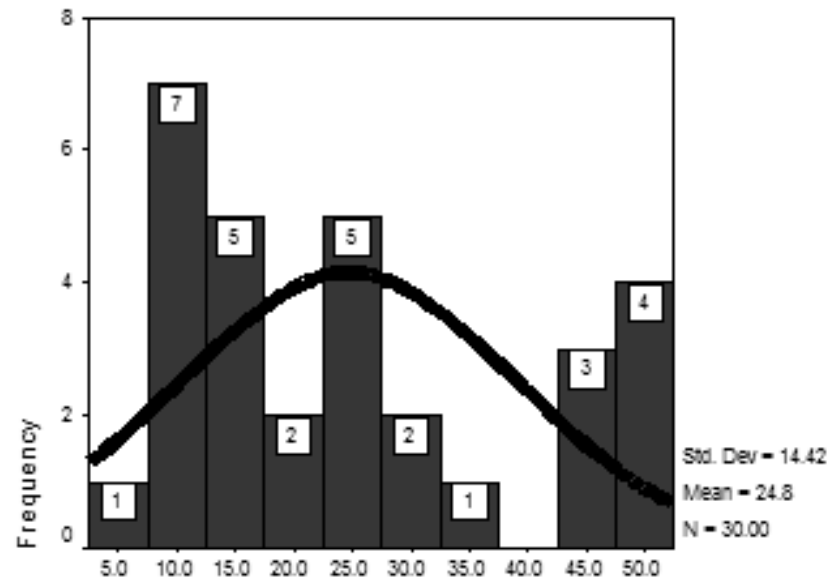

Figure 3. Histogram of learners' scores in cognitive group 
Table 7. Correlational results of age in cognitive group

\begin{tabular}{|ll|r|r|}
\hline & & AGE & $\begin{array}{c}\text { score-cog } \\
\text { nitive }\end{array}$ \\
\hline AGE & Pearson Correlation & 1 & $.506^{\star}$ \\
& Sig. (2-tailed) &. & .004 \\
& $\mathrm{~N}$ & 30 & 30 \\
\hline score-cognitive & Pearson Correlation & $.506^{*}$ & 1 \\
& Sig. (2-tailed) & .004 &. \\
& $\mathrm{~N}$ & 30 & 30 \\
\hline
\end{tabular}

**. Correlation is significant at the 0.01 level (2-tailed).

To address the hypotheses put forth at the beginning of the study, the scores obtained on the sixteen sessions of the study were submitted to an independent sample t-test. Furthermore, the hypothesis shows that there is a relationship between learners' age and reading scores in cognitive group. Besides, according to Pearson correlations the significant level is $\mathrm{p}=0.04$ and it is less than 0.05 and $\mathrm{r}=0.5$. Consequently, null hypothesis is rejected and alternative hypothesis is approved and there is significant meaningful level between two variables, so it certifies that the higher learners' age the higher reading scores in cognitive group will be.

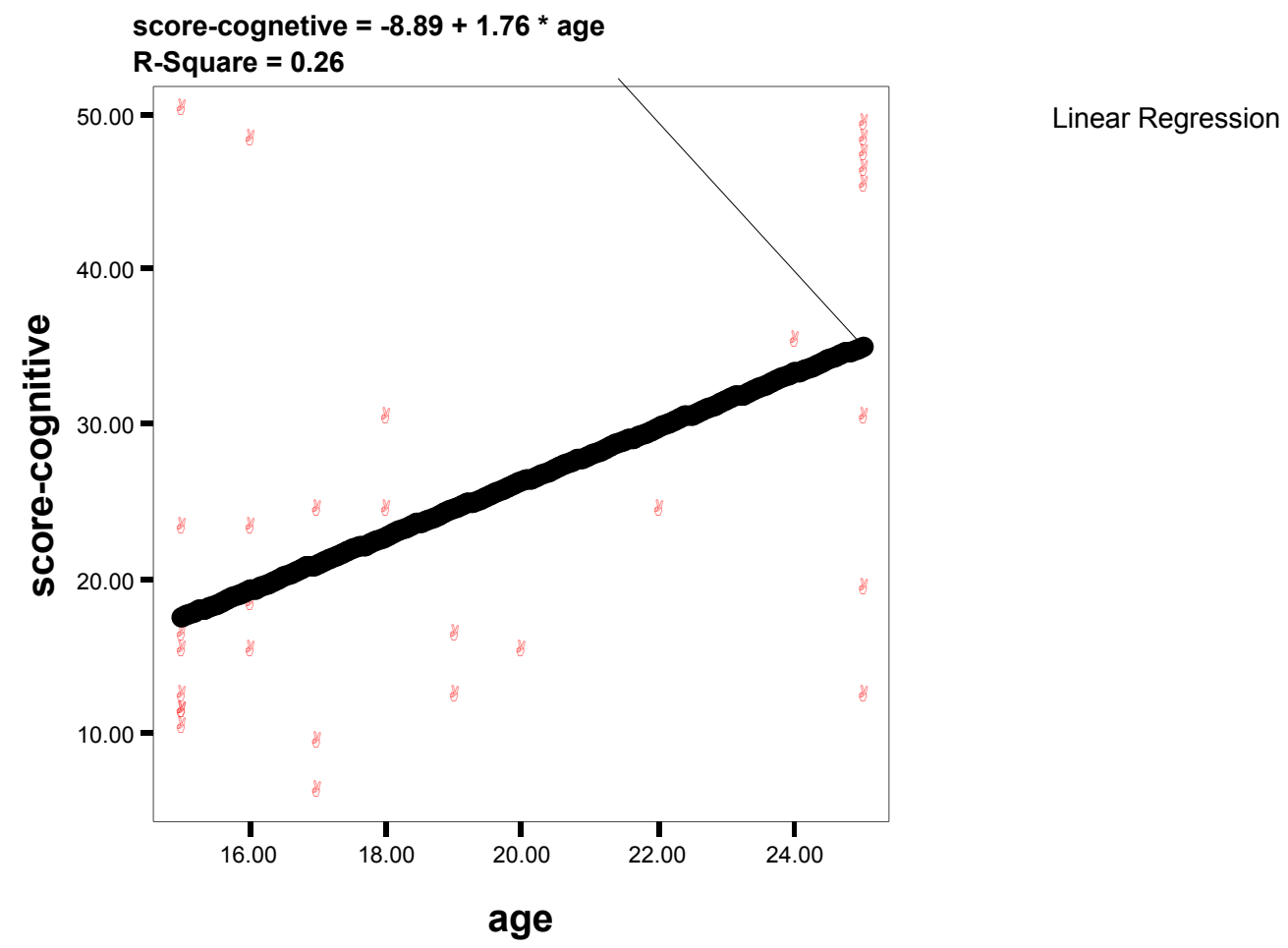

Figure 4. Interactive Graph results in cognitive group

Table 8. Independent T-test results of learners in cognitive group

Group Statistics

\begin{tabular}{|ll|r|r|r|c|}
\hline & SEX & $\mathrm{N}$ & Mean & Std. Deviation & $\begin{array}{c}\text { Std. Error } \\
\text { Mean }\end{array}$ \\
\hline score-cognitive & girl & 14 & 26.5000 & 14.97562 & 4.00240 \\
& boy & 16 & 23.2500 & 14.22908 & 3.55727 \\
\hline
\end{tabular}

Table 8 categorizes mean and standard deviation of cognitive group. It is obvious that learners by receiving different learning strategies have varied mean and standard deviations, so as it is shown, cognitive strategy group's mean among female learners is 26.50 with standard deviation of 14.97, and mean of 23.25, and standard deviation of 14.22 are respectively devoted to the male learners in cognitive group. Consequently, female learners' mean is more than male learners' mean and it shows its' significance and valued effects for participants in solving the problems in order to answer the reading comprehension questions. 
Table 9. Independent sample Test results of learners in cognitive group

Independent Samples Test

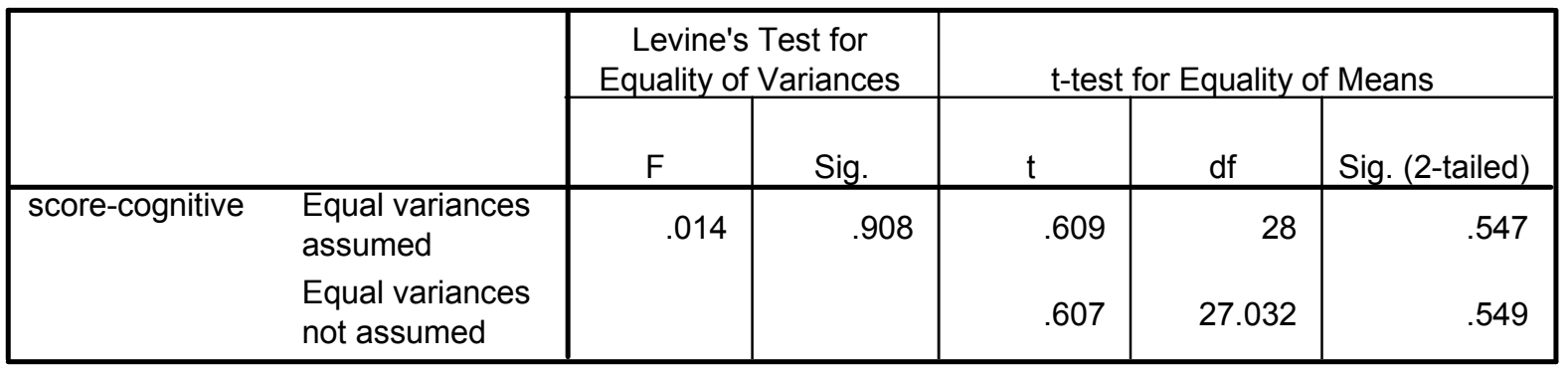

Based on results obtained of independent t-test evaluation, significant level of test is $\mathrm{p}=0.54$ and it is above 0.05 , so null hypothesis is approved and alternative hypothesis is rejected. At last, there are not significant differences in the reading scores of male and female learners in cognitive group.

Table 10. Pearson Correlation results of reading comprehension in cognitive group

Correlations

\begin{tabular}{|ll|r|r|}
\hline & & TOTALAVE & $\begin{array}{c}\text { score-cog } \\
\text { nitive }\end{array}$ \\
\hline TOTALAVE & Pearson Correlation & 1 & .041 \\
& Sig. (2-tailed) &. & .831 \\
& $\mathrm{~N}$ & 30 & 30 \\
\hline score-cognitive & Pearson Correlation & .041 & 1 \\
& Sig. (2-tailed) & .831 &. \\
& $\mathrm{~N}$ & 30 & 30 \\
\hline
\end{tabular}

According to data which was found of Pearson correlation $\mathrm{p}=0.83$ and more than 0.05 and $\mathrm{r}=0.04$, so null hypothesis is approved and alternative one would be rejected and accordingly between the two variables there is no relationship.

Table 11. Distribution of learners' sex in metacognitive group

SEX

\begin{tabular}{|ll|r|r|r|r|}
\hline & & & & & Cumulative \\
& & Frequency & Percent & Valid Percent & Percent \\
\hline Valid & girl & 23 & 76.7 & 76.7 & 76.7 \\
& boy & 7 & 23.3 & 23.3 & 100.0 \\
& Total & 30 & 100.0 & 100.0 & \\
\hline
\end{tabular}

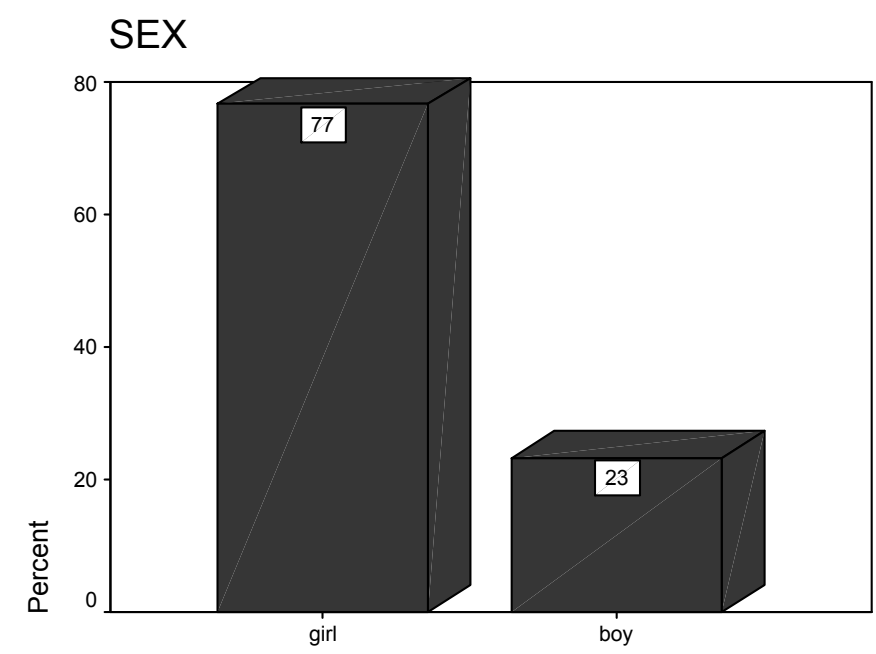

SEX

Figure 5. Histogram of learners' sex in metacognitive group 
Table 12. Distribution of learners' age in metacognitive group AGE

\begin{tabular}{|c|c|c|}
\hline $\bar{N}$ & $\begin{array}{l}\text { Valid } \\
\text { Missing }\end{array}$ & $\begin{array}{r}30 \\
0\end{array}$ \\
\hline $\mathrm{Me}$ & & 17.8000 \\
\hline & & 3.70833 \\
\hline & & 1.221 \\
\hline & & .427 \\
\hline Ra & & 11.00 \\
\hline & & 14.00 \\
\hline & & 25.00 \\
\hline
\end{tabular}

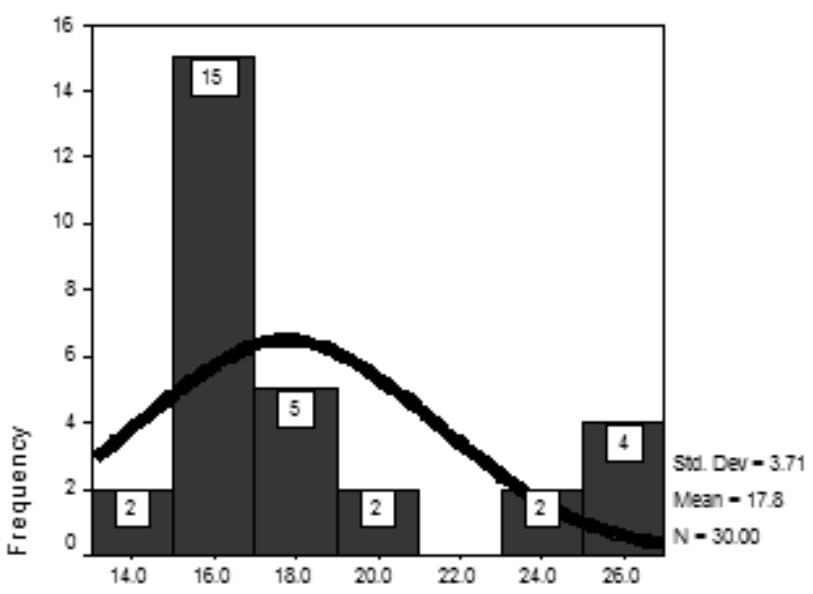

Figure 6. Histogram of learners' age in metacognitive group

Table 13. Distribution of learners' scores in metacognitive group score- meta cognetive

\begin{tabular}{|c|c|c|}
\hline $\bar{N}$ & $\begin{array}{l}\text { Valid } \\
\text { Missing }\end{array}$ & $\begin{array}{r}30 \\
0\end{array}$ \\
\hline $\mathrm{Me}$ & & 39.0000 \\
\hline & & 10.82781 \\
\hline & & -1.162 \\
\hline & & .427 \\
\hline Ral & & 36.00 \\
\hline & & 14.00 \\
\hline & & 50.00 \\
\hline
\end{tabular}

Based on the information in table 13 learners' reading scores mean in metacognitive group are 39 with the standard deviation of 10.82 and skewness of -1.16 . So, reading minimum score is 14 and maximum score is 50 .

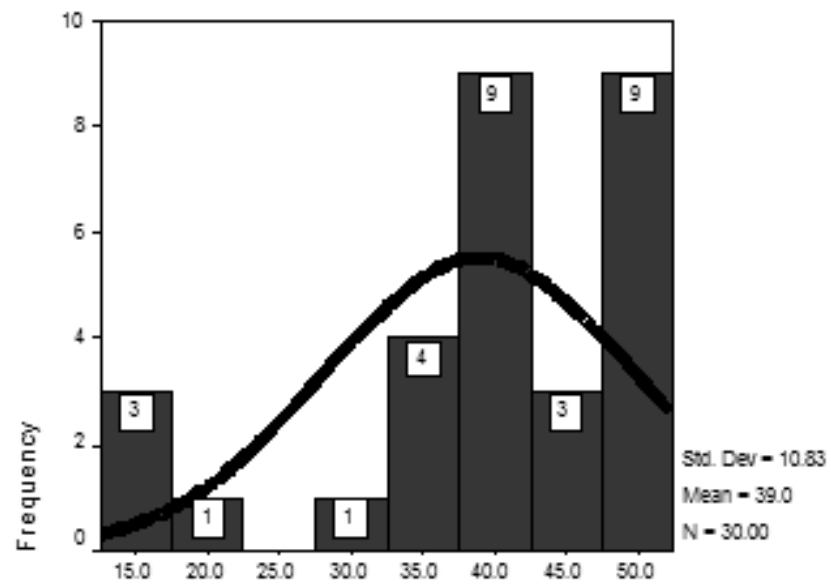

Figure 7. Histogram of learners' scores in metacognitive group 
Table 14. correlation results of learners' age in metacognitive group

Correlations

\begin{tabular}{|ll|r|r|}
\hline & & \multicolumn{1}{|c|}{$\begin{array}{c}\text { score- meta } \\
\text { cognitive }\end{array}$} \\
\hline AGE & Pearson Correlation & 1 & $-.427^{*}$ \\
& Sig. (2-tailed) &. & .019 \\
& $\mathrm{~N}$ & 30 & 30 \\
\hline score- metacognitive & Pearson Correlation & $-.427^{*}$ & 1 \\
& Sig. (2-tailed) & .019 &. \\
& $\mathrm{~N}$ & 30 & 30 \\
\hline
\end{tabular}

${ }^{*}$. Correlation is significant at the 0.05 level (2-tailed).

According to table 14 which was carried out by Pearson correlation, the significant level of test is $p=0.01$ and it is less than 0.05 , so null hypothesis was rejected and alternative hypothesis was certified. Furthermore, between two variables there is a significant reversed relationship. Besides, increasing learners' age leads to a reduction in reading scores in metacognitive group.

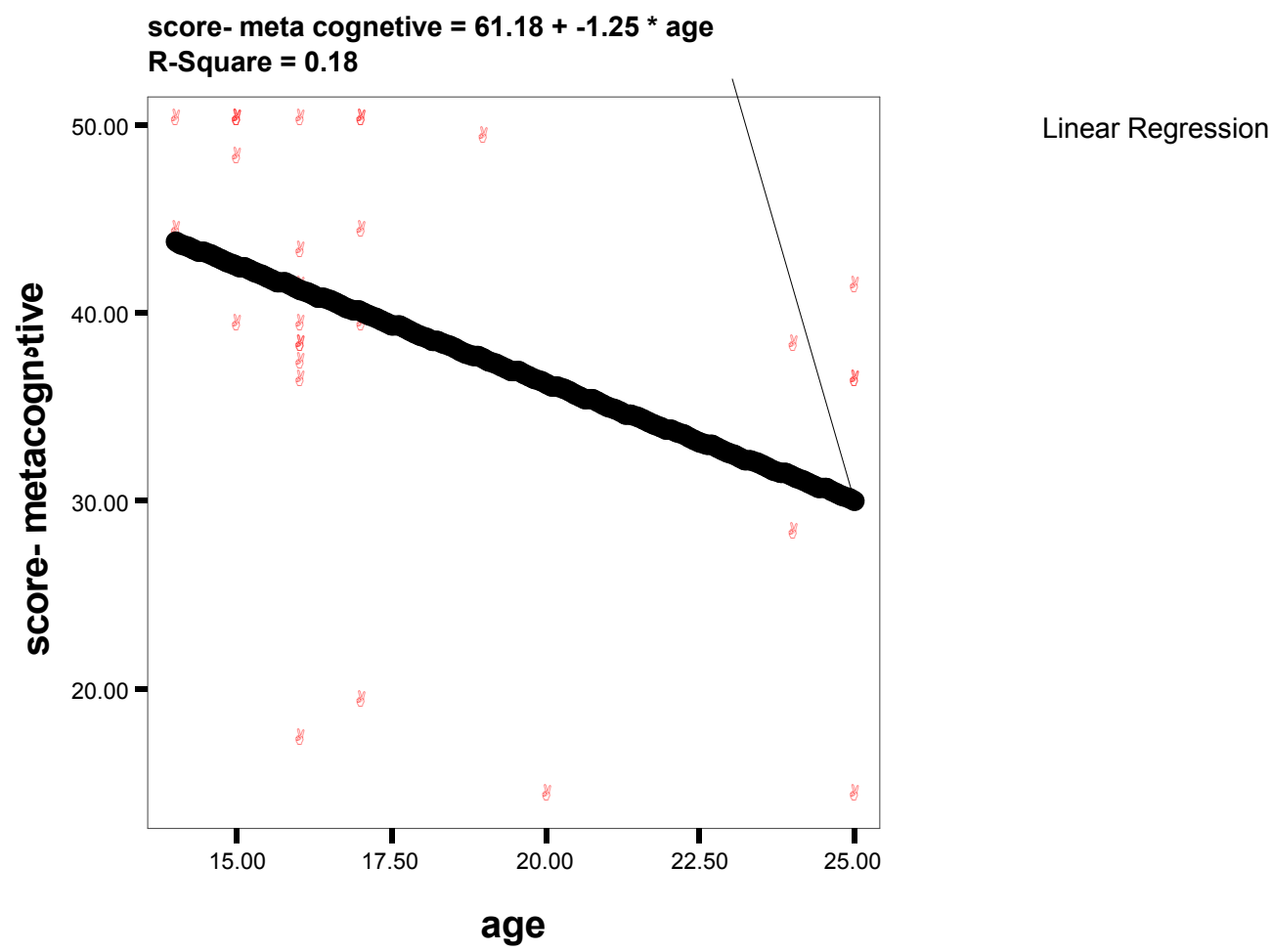

Figure 8. Interactive Graph results in metacognitive group

Table 15. Statistics results of sex in metacognitive group based on their sex

\begin{tabular}{|ll|r|r|r|r|}
\hline & SEX & $\mathrm{N}$ & Mean & Std. Deviation & \multicolumn{1}{c|}{$\begin{array}{c}\text { Std. Error } \\
\text { Mean }\end{array}$} \\
\hline score- metacognitive & girl & 23 & 38.7826 & 12.20267 & 2.54443 \\
& boy & 7 & 39.7143 & 4.46148 & 1.68628 \\
\hline
\end{tabular}

Table 15 classifies mean and standard deviation of metacognitive group. It is obvious that learners by receiving metacognitive strategies have varied mean and standard deviations; so as it is shown metacognitive strategy group's mean among female learners is 38.78 with standard deviation of 12.20 , and mean of 39.71 and standard deviation of 4.46 are respectively devoted to the male learners in metacognitive group. Accordingly, male learners' mean is more than female learners' mean and it shows its' significance and valued effects for participants in solving the problems in answering the reading comprehension questions by employing metacognitive strategies compared to the other strategies. 
Table 16. Independent Sample T-test Results in metacognitive group

Independent Samples Test

\begin{tabular}{|c|c|c|c|c|c|c|}
\hline & \multicolumn{2}{|c|}{$\begin{array}{l}\text { Levine's Test for } \\
\text { Equality of Variances }\end{array}$} & \multicolumn{3}{|c|}{ t-test for Equality of Means } \\
\hline & & $\mathrm{F}$ & Sig. & $\mathrm{t}$ & df & Sig. (2-tailed) \\
\hline score- metacognitive & $\begin{array}{l}\text { Equal variances } \\
\text { assumed } \\
\text { Equal variances } \\
\text { not assumed }\end{array}$ & 4.692 & .039 & $\begin{array}{l}-.196 \\
-.305\end{array}$ & $\begin{array}{r}28 \\
26.69\end{array}$ & $\begin{array}{l}.846 \\
.763\end{array}$ \\
\hline
\end{tabular}

Due to the t-test results it can be observed that significant level of test is $p=0.76$ and it is more than 0.05 , so null hypothesis is certified and alternative hypothesis is rejected. Furthermore, there are not meaningful differences in males and female learners' reading scores in metacognitive group.

Table 17. Pearson Correlational Results in metacognitive group

\begin{tabular}{|ll|r|r|}
\hline & & $\begin{array}{c}\text { score- meta } \\
\text { cognitive }\end{array}$ \\
\hline TOTALAVE & TOTALAVE & 1 & -.231 \\
& Sig. (2-tailed) &. & .220 \\
& $\mathrm{~N}$ & 30 & 30 \\
\hline score- metacognitive & Pearson Correlation & -.231 & 1 \\
& Sig. (2-tailed) & .220 &. \\
& $\mathrm{~N}$ & 30 & 30 \\
\hline
\end{tabular}

Table 17 shows that there are not meaningful differences in learners' reading scores in metacognitive group.

Table 18. Distribution of learners' sex in social-affective group

\begin{tabular}{|c|c|c|c|c|c|}
\hline & & Frequency & Percent & Valid Percent & $\begin{array}{c}\text { Cumulative } \\
\text { Percent }\end{array}$ \\
\hline \multirow[t]{3}{*}{ Valid } & girl & 20 & 66.7 & 66.7 & 66.7 \\
\hline & boy & 10 & 33.3 & 33.3 & 100.0 \\
\hline & Total & 30 & 100.0 & 100.0 & \\
\hline
\end{tabular}

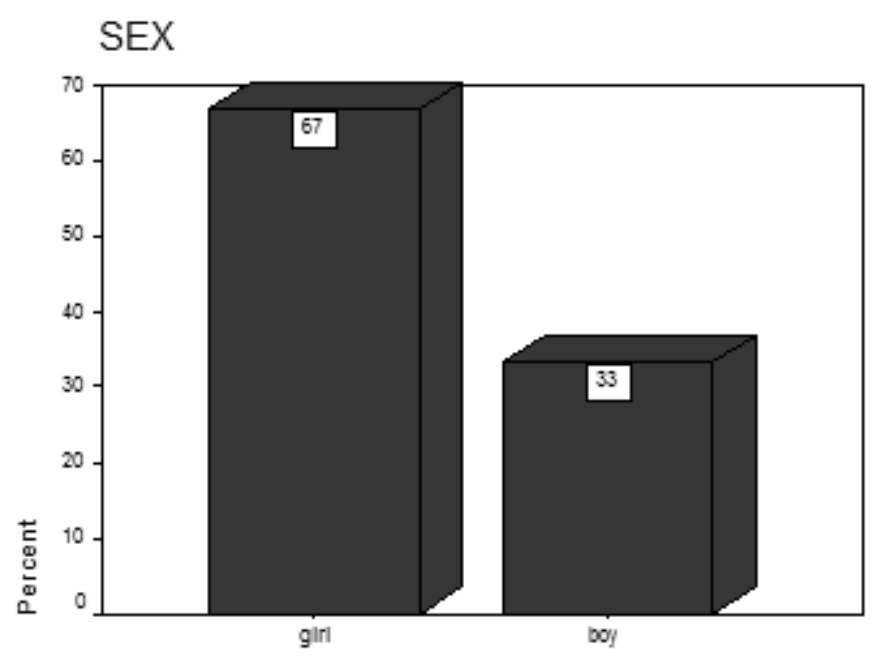

Figure 9. Histogram of learners' sex in social-affective group 
Table 19. Distribution of learners' age in social-affective group AGE

\begin{tabular}{|c|c|}
\hline $\mathrm{N}$ & $\begin{array}{r}30 \\
0\end{array}$ \\
\hline Mean & 18.2000 \\
\hline Std. Deviation & 3.78199 \\
\hline Skewness & 1.035 \\
\hline Std. Error of Skewness & .427 \\
\hline Range & 10.00 \\
\hline Minimum & 15.00 \\
\hline Maximum & 25.00 \\
\hline
\end{tabular}

Table 20. Distribution of learners' age in social-affective group

AGE

\begin{tabular}{|rr|r|r|r|r|}
\hline & & & & $\begin{array}{c}\text { Cumulative } \\
\text { Percent }\end{array}$ \\
\hline Valid & 15.00 & Frequency & Percent & Valid Percent & 30.0 \\
& 9 & 30.0 & 30.0 & 50.0 \\
16.00 & 6 & 20.0 & 20.0 & 60.0 \\
17.00 & 3 & 10.0 & 10.0 & 70.0 \\
18.00 & 3 & 10.0 & 10.0 & 76.7 \\
19.00 & 2 & 6.7 & 6.7 & 80.0 \\
23.00 & 1 & 3.3 & 3.3 & 83.3 \\
24.00 & 1 & 3.3 & 3.3 & 100.0 \\
25.00 & 5 & 16.7 & 16.7 & \\
Total & 30 & 100.0 & 100.0 & \\
\hline
\end{tabular}

AGE

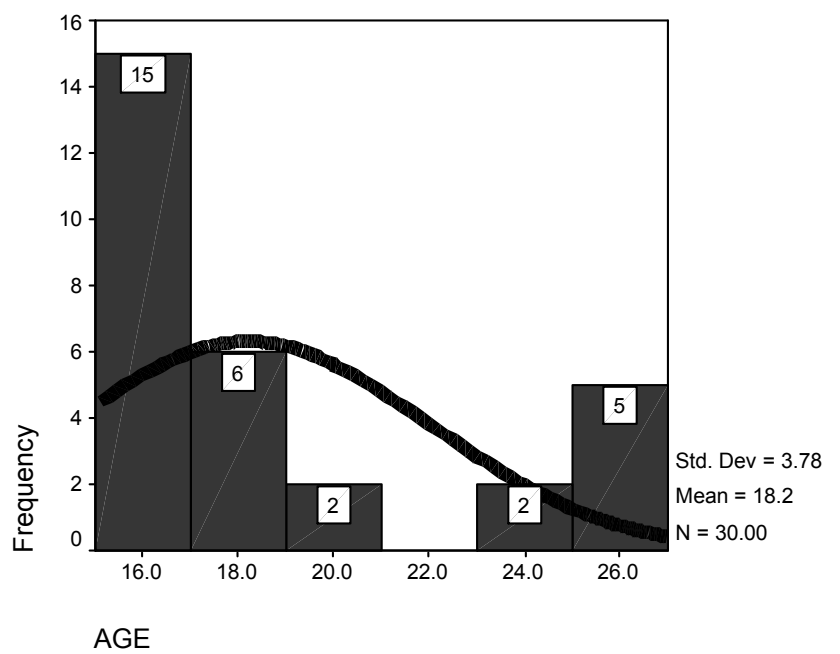

Figure 10. Histogram of learners' age in social-affective group

Table 21. Statistics distribution of learners' reading scores in social-affective group score- social affective

\begin{tabular}{|c|c|c|}
\hline$N$ & $\begin{array}{l}\text { Valid } \\
\text { Missing }\end{array}$ & $\begin{array}{r}30 \\
0\end{array}$ \\
\hline & & 30.2667 \\
\hline & & 8.38691 \\
\hline & & .743 \\
\hline & & .427 \\
\hline & & 37.00 \\
\hline & & 13.00 \\
\hline & & 50.00 \\
\hline
\end{tabular}


Reading mean score of learners in social-affective group is 30.26 with the standard deviation of 8.38 and skewness of 0.74 , in which the minimum score is 13 and maximum score is 50 .

Table 22. Distribution of learners' score in social-affective group

score- social/affective

\begin{tabular}{|c|c|c|c|c|c|}
\hline & & Frequency & Percent & Valid Percent & $\begin{array}{c}\text { Cumulative } \\
\text { Percent }\end{array}$ \\
\hline \multirow[t]{16}{*}{ Valid } & 13.00 & 1 & 3.3 & 3.3 & 3.3 \\
\hline & 14.00 & 1 & 3.3 & 3.3 & 6.7 \\
\hline & 25.00 & 4 & 13.3 & 13.3 & 20.0 \\
\hline & 26.00 & 2 & 6.7 & 6.7 & 26.7 \\
\hline & 27.00 & 4 & 13.3 & 13.3 & 40.0 \\
\hline & 28.00 & 3 & 10.0 & 10.0 & 50.0 \\
\hline & 29.00 & 1 & 3.3 & 3.3 & 53.3 \\
\hline & 30.00 & 5 & 16.7 & 16.7 & 70.0 \\
\hline & 32.00 & 1 & 3.3 & 3.3 & 73.3 \\
\hline & 33.00 & 2 & 6.7 & 6.7 & 80.0 \\
\hline & 35.00 & 1 & 3.3 & 3.3 & 83.3 \\
\hline & 38.00 & 1 & 3.3 & 3.3 & 86.7 \\
\hline & 39.00 & 1 & 3.3 & 3.3 & 90.0 \\
\hline & 48.00 & 1 & 3.3 & 3.3 & 93.3 \\
\hline & 50.00 & 2 & 6.7 & 6.7 & 100.0 \\
\hline & Total & 30 & 100.0 & 100.0 & \\
\hline
\end{tabular}

score- social/affective

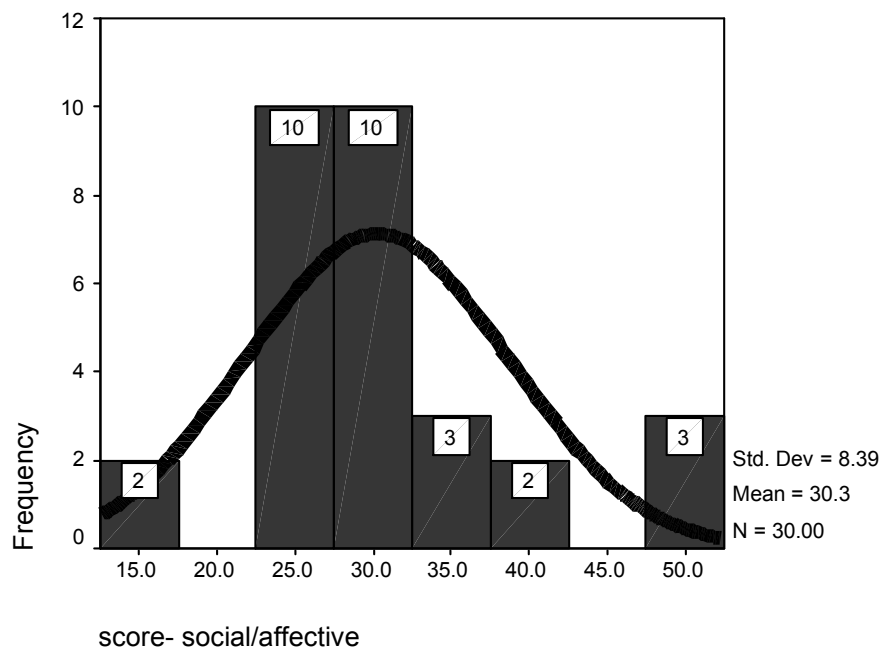

Figure 11. Histogram of learners' scores in social-affective group

Table 23. Correlational results of learners' age and scores in social-affective group

Correlations

\begin{tabular}{|ll|r|r|}
\hline & & \multicolumn{1}{|c|}{$\begin{array}{c}\text { score- social } \\
\text { /affective }\end{array}$} \\
\hline AGE & Pearson Correlation & 1 & .083 \\
& Sig. (2-tailed) &. & .663 \\
& $\mathrm{~N}$ & 30 & 30 \\
\hline score- social/affective & Pearson Correlation & .083 & 1 \\
& Sig. (2-tailed) & .663 &. \\
& $\mathrm{~N}$ & 30 & 30 \\
\hline
\end{tabular}


Table 23 reflects another hypothesis in this study which indicates that there is a relationship between age and reading scores of learners in social affective group and according to pearson correlation $\mathrm{p}=0.66$ and it is more than 0.05 so the results rejects the hypothesis and manifests that there is not any relationship between them.

Table 24. T-test results in social-affective group

\section{Group Statistics}

\begin{tabular}{|ll|r|r|r|c|}
\hline & SEX & $\mathrm{N}$ & Mean & Std. Deviation & $\begin{array}{c}\text { Std. Error } \\
\text { Mean }\end{array}$ \\
\hline score- social/affective & girl & 20 & 31.0500 & 8.99985 & 2.01243 \\
& boy & 10 & 28.7000 & 7.18099 & 2.27083 \\
\hline
\end{tabular}

Conspicuously, table 24 illustrates mean and standard deviation of social-affective group. It is obvious that learners by applying social/affective strategies have varied mean and standard deviations, so as it is shown social-affective strategy group mean among female learners is 31.05 with the standard deviation of 8.99 , and mean of 28.70 , and standard deviation of 7.18 are respectively devoted to the male learners. Accordingly, female learners' mean is more than male learners' mean and it shows its' significant and valued effects for participants in social-affective group by solving the problems in answering the reading comprehension questions compared to the other strategies. Besides, there is a significant point in the results which shows that female learners are more affective people and by making the class atmosphere full of socio-affective strategies due to girls' strong interest in these strategies their reading scores will increases.

Table 25. Independent Sample Test results in social/affective strategy group

Independent Samples Test

\begin{tabular}{|c|c|c|c|c|c|c|}
\hline & \multicolumn{2}{|c|}{$\begin{array}{l}\text { Levene's Test for } \\
\text { Equality of Variances }\end{array}$} & \multicolumn{3}{|c|}{ t-test for Equality of Means } \\
\hline & & $\mathrm{F}$ & Sig. & $t$ & df & Sig. (2-tailed) \\
\hline score- social/affective & $\begin{array}{l}\text { Equal variances } \\
\text { assumed }\end{array}$ & .532 & .472 & .717 & 28 & .479 \\
\hline & $\begin{array}{l}\text { Equal variances } \\
\text { not assumed }\end{array}$ & & & .774 & 22.201 & .447 \\
\hline
\end{tabular}

Generally, based on the independent t-test results, $\mathrm{p}=0.47$ and it is above 0.05 significant level, so null hypothesis is approved and alternative hypothesis is rejected; furthermore, there is not meaningful differences among learners' reading scores in social-affective group.

Table 26. Pearson Correlational results in social-affective group

Correlations

\begin{tabular}{|ll|r|r|}
\hline & & TOTALAVE & $\begin{array}{c}\text { score- social/ } \\
\text { affective }\end{array}$ \\
\hline TOTALAVE & Pearson Correlation & 1 & .065 \\
& Sig. (2-tailed) &. & .733 \\
& $\mathrm{~N}$ & 30 & 30 \\
\hline score- social/affective & Pearson Correlation & .065 & 1 \\
& Sig. (2-tailed) & .733 &. \\
& $\mathrm{~N}$ & 30 & 30 \\
\hline
\end{tabular}

Table 26 shows that based on the Pearson correlation results, $\mathrm{p}=0.733$ and it is above 0.05 significant level, so null hypothesis is approved and alternative hypothesis is rejected; furthermore, there is not meaningful differences among learners' reading scores in social-affective group.

\section{Discussion}

This study was conducted by providing a placement test (Oxford University Press and University of Cambridge Local Examinations Syndicate) to 130 selected participants of upper-intermediate students, which finally 90 of them were chosen as homogeneous ones. After finding the homogeneity of the participants, learners were randomly divided into three groups and three main learning strategies (cognitive, metacognitive, social/affective) based on Brown's (2000) 
taxonomies were taught and maintained in each group. Additionally, three reading passages which were proper to the participants' proficiency level were chosen (TOEFL test 2001).

The SPSS software was applied to analyze the obtained data, which consisted of descriptive statistics and analytical method (t-test, and Pearson correlation). In this study, the findings unmask the frequency of employing metacognitive, cognitive, and social/affective strategies and also administering them in the classes which may help learners to elevate their ability to answer reading comprehension passages. Moreover, it makes crystal clear that the groups with higher mean in reading comprehension scores, employed the received strategy better which were supposed to be assessed. Then, the distinctions and contrasts among the groups who had the reading comprehension mean lower than other groups were expected to be assessed. These outcomes may help us to understand if the reading comprehension can be dominated by the use of particular language learning strategies, the consequence of that is to answer tests better than before and use some strategies which far overweighed the other ones.

This study aimed to carry out the evaluation of metacognitive, cognitive and social/affective strategies as essential components of learning strategies and their relationship with EFL learners' reading comprehension promotion. Furthermore, findings showed that in cognitive group according to Pearson correlations the significant level is $\mathrm{p}=0.04$ and it is less than 0.05. Accordingly, in cognitive group null hypothesis is rejected and alternative hypothesis is approved and there is significant level between two variables. It means that the higher learners' age, the higher reading scores in cognitive group will be. Besides, the mean and standard deviation of cognitive group is obvious and shows that learners by receiving different learning strategies have varied mean and standard deviations; so as it is clear cognitive strategy group's mean among female learners is 26.50 with standard deviation of 14.97 , and mean of 23.25 , and standard deviation of 14.22 are respectively devoted to the male learners in cognitive group. Consequently, female learners' mean is more than male's mean and it shows its' significant and valued effects for participants in solving the problems in answering the reading comprehension questions by employing cognitive strategies. Conspicuously, results in cognitive strategy and its relationship with reading comprehension obtained out of independent t-test evaluation showed a significant level of test is $\mathrm{p}=0.54$ and it is above 0.05 , so null hypothesis is approved and alternative hypothesis is rejected. At last, there are not any significant differences in reading scores of males and females learners in cognitive group. Accordingly, data which was found of Pearson correlation presented that $\mathrm{p}=0.83$ and more than 0.05 and $\mathrm{r}=0.04$; so, again null hypothesis was approved and alternative one would be rejected and showed that between two variables there is no relationship.

Absolutely, in metacognitive strategy and reading comprehension relationship findings accompanied with Pearson correlation which was carried out, showed that significant level of test is $p=0.01$ and it is less than 0.05 , so null hypothesis was rejected and alternative hypothesis was certified, furthermore between two variables there is significant reversed relationship and it has been distributed well. So, the higher learners' age magnitude the less reading scores in metacognitive group. Obviously, mean and standard deviation of metacognitive group manifests that learners by getting metacognitive strategy have interesting mean and standard deviations; so as it is shown metacognitive strategy group's mean among female learners is 38.78 with standard deviation of 12.20 , and mean of 39.71 , and standard deviation of 4.46 which were respectively devoted to the male learners in metacognitive group. Finally, male learners' mean is more than female learners' mean and illustrate its' significant and valued effects for participants in solving the problems in answering the reading comprehension questions compared to the other strategies. On the other hand, due to the t-test results it can be observed that significant level of test is $\mathrm{p}=0.76$ and is more than 0.05 , so null hypothesis is certified and alternative hypothesis is rejected. Furthermore, there are not any meaningful differences in males and female learners' reading scores in metacognitive group.

In the end, results in the last group reflects another hypothesis in this study which declares that there is going to be a relationship between age and reading scores of learners in social affective group but according to Pearson correlation results $p=0.66$ and it is more than 0.05 , so the findings rejects the hypothesis and manifests that there is not any relationship between them only by considering the age level.

Basically, mean and standard deviation of social-affective group signifies that learners by receiving socio-affective strategies have varied mean and standard deviations; furthermore, social-affective strategy group's mean among female learners is 31.05 with standard deviation of 8.99 , and mean of 28.70 , and standard deviation of 7.18 are respectively devoted to the male learners. Honestly, female learners' mean is more than male groups' mean and here again it shows its' significant and valued effects for participants in social-affective group by solving the problems in replying the reading comprehension questions compared to the other strategies. Moreover, there is a significant point in the results and it shows that female learners are more affective people and by making the class atmosphere full of socio-affective strategies, girls are in line with these strategies and get along well with the social-affective strategies so their reading scores level increases by making the girls familiar with this strategies.

Mainly, based on the independent t-test results, $\mathrm{p}=0.47$ and it is above 0.05 significant level, so null hypothesis is approved and alternative hypothesis is rejected; furthermore, there is not meaningful differences among learners' reading scores in social-affective group. Findings, show that based on the Pearson correlation results, $\mathrm{p}=0.733$ and it is above 0.05 significant level, so null hypothesis is approved and alternative hypothesis again is rejected; furthermore, there is not meaningful differences among learners' reading scores and socio-affective strategies in the last group (social-affective). 


\section{Conclusion}

To make a long story short, the main focus of this study was to understand that metacognitive, cognitive, and social/affective strategies are related to EFL learners' reading comprehension; so due to getting evidence, the written data were submitted to a series of independent sample t-test and Pearson correlations. The results of these tests were an indication of the statistically significant differences among the experimental groups. By sharing learning strategies and especially metacognitive awareness, learners can do their best to find new ways of learning and being familiar with these learning strategies. Hence, the researcher tried to assess language learning strategies as positive predictors in promoting EFL learners' learning role; specifically, metacognitive strategy was the most efficient one among other strategies. Finally, it is necessary to remind that there are some noticeable points that uncover the importance of learning strategies in enhancing EFL learners' reading comprehension, especially metacognitive awareness that includes metacognitive strategies which its role is undeniable.

It is noticeable that upper intermediate learners who received cognitive strategies were not as successful as metacognitive group, so it was tangible for the researcher specially when some strategies in cognitive weren't transferable to learners' mind and maybe for the lack of that strategies' circumstances, learners rejected to apply them.

Obviously, findings in metacognitive strategy group indicate that learners have applied a higher level of metalinguistic awareness. O'Malley (1985) illustrated that metalinguistic knowledge is considered as a term to express executive function, strategies which need planning for learning, thinking about the learning process as it is taking place, monitoring of one's production or comprehension and evaluating learning after an activity is completed. Most of the effective learners with certain aim for learning and long lasting abilities of self-monitoring, self-awareness, selfmanagement, self-evaluation compared to poor learners have better capabilities to arrange and scheme their learning properly, monitor their learning processes, and measure their attainments one after another. The model which was investigated provided repeated exposure to and practice with metacognitive strategies in order to raise learners' awareness of the processes underlying successful reading comprehension, while simultaneously incorporating a select number of cognitive and socio-affective strategies.

As Stern (1983) believed, learners who received social/affective strategies knew how much important were this kind of strategy taxonomy, and they could comprehend how effectively handle their feeling who has inclination to deliberately look for chances in order to negotiate as mutual actions with foreign language users efficiently to be communicatively competent. This study tends to explain the application of language learning strategies and their relation with reading comprehension. The findings reveal that the learners weren't aware of so many kinds of learning strategies, those who had employed metacognitive strategies and its subcategories such as awareness in metacognition, used monitoring and evaluation of their own processes, were more successful compared to the other ones. Learners also took the advantage of cognitive strategies, which have a direct influence on the processing of information. Social/affective strategies were a way to interact and negotiate with other EFL speakers in a relaxed and low stress situation. Additionally, in socioaffective strategy results, there was a significant point which described those female learners' results in this group out performed male learners, because of girls' strong emotional feelings they could understand very well the mentioned items in these strategies and also employed those socio-affective strategies as the best ones.

\section{References}

Akın, A., Abacı, R., \& Çetin, B. (2007). The validity and reliability of the Turkish version of the metacognitive awareness inventory, Educational Sciences: Theory \& Practice, 7(2), 671-678.

Alexander, P.A., \& Jetton, T.L. (2000). Learning from text: A multidimensional And developmental perspective. In M.L. Kamil, P.B. Mosenthal, P.D. Pearson, \& R.Barr (Eds.), Handbook of reading research (3, 285-310). Mahwah, NJ. Anderson, N. J. (2002). The role of metacognition in second language teaching and learning. Retrieved from ERIC database. (ED 463659).

Artzt . A. F..\& Armour. Thomas. E. (1992). Development of a cognitive-metacognitive frameworkfor protocol analysis of mathematical problem solving in small groups.Cognition and Instruction, 9, 137-175.

Astington, J.W. (1993). The Child's Discovery of Mind. Cambridge, MA: Harvard University Press.

Baird, J. R. (1998). Metacognition, purposeful inquiry and conceptual change. In E. Hegarty-Hazel (Ed.), The student laboratory and the science curriculum. London: Routledge.

Baker, L. (1989).Metacognition, comprehension monitoring, and the adult reader. Educational Psychology Review 1: 338.

Bazerman, C. (1985). Physicist reading physics: Schema-laden purposes and purpose-laden schema. Written Communication, 2(1), 3-23.

Boakye, N. (2011). A Multifaceted Model FOR Designing Reading Development Programs for L2 Learners at Tertiary Level. Per Linguam, 27(2), 114-132.

Borkowski, J.G. (1992). Metacognitive Theory: A framework for teaching literacy, writing and math skills, Journal of learning disabilities, 25(4), 253-257.

Brown, H. D. (2000). Principles of Language Learning and Teaching [M]. $4^{\text {th }}$ ed. NY: Longman.

Brown, A. (1987). Metacognition, executive control, self-regulation, and other more mysterious mechanisms. In F.Weinert \& R. Kluwe, eds., Metacognition, Motivation, and Understanding (pp. 65-116). Hillsdale, NJ: Erlbaum. 
Bus, A. (2001). Parent-child book reading through the lens of attachment theory. In Verhoeven, L \& C Snow (Eds), Literacy and motivation: Reading Engagement in individuals and groups. Mahwah, NJ: Lawrence Erlbaum.

Butler, D.L. \& Winne, P.H. (1995). Feedback and self-regulated learning: A theoretical synthesis. Review of Educational Research, 65, 245-282.

Carrell, P. L. (1998). Metacognitive Awareness and Second Language Reading. The Modern Language Journal, 73 (2), 121-134.

Chastain, K. (1998). Developing second-language skills: Theory and practice. $3^{\text {rd }} \quad$ ed. Harcourt Brace Jovanovich Publishers.

Flavell, J. H. (1979). Metacognition and cognitive monitoring: Anew area of cognitive developmental inquiry. American Psychologist, 34(10), 906-911.

Flavell, J. H. (1976). Metacognitive aspects of problem solving In Resnick, L.B. The Nature of Intelligence, 12, 231235. Lawrence Erlbaum Associates.

Flavell, J.H. \& Wellman, H.M. (1977). Meta memory. In R.V. Kail \& J.W. Hagen (Eds.), Perspectives on the development of memory and cognition.

Flavell, J.H. (1987). Speculations about the nature and development of metacognition. In F.Weinert\& R. Kluwe, eds., Metacognition, motivation, and understanding (pp. 21-29).Hillsdale, NJ: Erlbaum.

Garner, R. (1990). When children and adults do not use learning strategies:Toward a theory of settings. Review of Educational Research, 60, 517-529.

Garner, R. \& Alexander, P.A. (1989). Metacognition: Answered and unanswered questions, Educational Psychologist, 24, 143-158.

Glenberg, A. M., \& Epstein, W. (2005). Inexpert calibration of comprehension, Memory \& Cognition, 15, 84-93.

Greaney, V. (1996). Reading in developing countries: Problems and issues.

Greaney, V (Ed), Promoting reading in developing countries. Washington DC: International Reading Association.

Hall, L.K. \& Cremer, E.M. (2000, November). Metacognitive judgments of exam performance. Presented at the 41st Meeting of the Psychonomic Society, New Orleans, LA.

Hartman, H.H. \& Sternberg, R.J. (1993). A broad BACEIS for improving thinking. Instructional Science 21: 401-425.

Jacobs, J.E. \& Paris, S.G. (1987). Children's metacognition about reading: Issues In definition, measurement, and instruction. Educational Psychologist 22, 255-278.

Joseph, N. (2010). Metacognition Needed: Teaching Middle and High School Students to Develop Strategic Learning Skills, Preventing School Failure, Volume 54, 2(2010), 99-103, Heldref Pub.

Kuhn, D. (1991). The skills of argument, New York: Cambridge University Press.

Kuhn, D., Schauble, L. \& Garcia-Mila, M. (1992). Cross-domain development of scientific reasoning. Cognition and Instruction 9: 285-327.

Livingston, J. A. (1997). Meta-cognition: An Overview. Retrieved August 11, 2006.

Memnun, D.S. \& Akkaya, R. (2009). The levels of meta-cognitive awareness of primary teacher trainees, Procedia social and behavioral Sciences 1(2009), 1919-1923.

Montgomery, D.E. (1992). Young children's theory of knowing: The development of a folk epistemology. Developmental Review 12: 410-430.

Niven, P. (2005). Exploring first year students and their lecturers constructions of what it means to read in a humanities discipline: A conflict of frames? South African Journal of High Education, 19(4), 777-789.

O'Mally, J. M., \& Chamot, A. (1990). Learning strategies in second language acquisition (The Cambridge Applied Linguistics Series). Cambridge: Cambridge University Press.

O'Malley, J.M., Chamot, A.U., Stewner-Manzanares, G., Kupper, L. \& Russo, R.P. (1985), Learning strategy used by beginning and intermediate ESL students', Language Learning, 35, 21-46.

Oxford, R.L. (1990). Language Learning Strategies: What Every Teacher Should Know .New York, New bury House Publishers.

Oxford, R.L. (1990). Missing Link: Evidence from Research on Language Learning Styles and Strategies. In Alatis, J., editor, Georgetown University Round Table on Languages and Linguistics, Washington D.C: Georgetown University Press, $438-58$.

Oxford, R. L. (1990). Language learning strategies in a nutshell: Update and ESL suggestions. In J.C. Richards \& W. A. Renandya (Eds.), Methodology in Language Teaching: An Anthology of Current Practice (pp.124-32). Cambridge: Cambridge University Press.

Pintrich, P. R., Wolters, C. A., \& Baxter, G. P. (2000). Assessing meta-cognition and self-regulated learning. In: G. Schraw\& J. C. Impara (Eds.), Issues in the measurement of meta-cognition (43-97). Lincoln NE: Buros Institute of Mental Measurements.

Pintrich, P. R., Smith, D. A., Garcia, T., \& McKeachie, W. J. (1993). Reliability and predictive validity of the Motivated Strategies for Learning Questionnaire (MSLQ). Educational and Psychological Measurement, 53, 801-813. 
Pintrich, P. R. \& Garcia, T. (1994). Self-regulated learning in college students: knowledge, strategies, and motivation, in: P. R. Pintrich, D. R. Brown \& C. E.Weinstein (Eds) Student motivation, cognition, and learning. Hillsdale, NJ,Erlbaum, 113-133.

Pressley, M., Borkowski, J.G. \& Schneider, W. (1987). Cognitive strategies: Good strategy users coordinate metacognition and knowledge. In R. Vasta \&nG.Whitehurst, eds., Annals of Child Development, Vol. 5 (pp. 890-129). Greenwich, CT: JAI Press.

Pressley, M. \& Ghatala, E.S. (1990). Self-regulated learning: Monitoring Learning from text. Educational Psychologis,t 25, 19-33.

Pressley, M., \& Afflerbach, P. (1995). Verbal protocols of reading: The nature of constructively responsive reading. Hillsdale NJ: Erlbaum.

Pressley, M., Brown, R., El-Dinary, P., \& Afflerbach, P. (1995). The comprehension instruction that students need: Instruction fostering constructively responsive reading. Learning Disabilities Research \& Practice, 10(4), 215-224.

Pressley, M., Wharton-McDonald, R. (1997).Skilled comprehension and its development through instruction. School Psychology Review, 26(3), 448-466.

Pressley, M. (2000). What should comprehension instruction be the instruction of? In M.L. Kamil, P.B. Mosenthal, P.D. Pearson, \& R. Barr (Eds.), Handbook of reading research: Volume III. Mahwah NJ: Erlbaum.

Presley, M. (2002). Metacognition and self-regulated comprehension. In A. E.Farstrup \& S.J. Samuels (Eds.), What Research Has to Say About Reading Instruction (pp. 291-309). Newark, DE: International Reading Association.

Pressley, M. \& Gaskins, I. W. (2006). Metacognitively competent reading comprehension is constructively responsive reading: How can such reading be developed in students? Metacognition Learning, 1, 99-113.

Richards, J. and Rodgers, S. (2001). Approaches and Methods in Language Teaching. Cambridge University Press.

Rubin, J., (1975). What the "good language learner" can teach us. TESOL Quarterly, 9, 41-51.

Rubin, J. (1975) "What the good language learner can teach us". In TESOL Quarterly, 9, pp. 41-51.

Rubin, J. (1987). Learner strategies: theoretical assumptions, research history and typology. In Wenden, and J.Rubin.(eds.). Learner strategies in language Learning. Prentice Hall International, (UK) Ltd.

Schraw, G. \& Sperling Denison, R. (1994). Assessing metacognitive awareness. Kluwer Contemporary Educational Psychology, 19, pp. 460-475.

Schraw, G. (1994). The effect of metacognitive knowledge on local and global monitoring. Contemporary Educational Psychology, 19, 143-15.

Schraw, G., Dunkle, M.E., Bendixen, L.D. \&Roedel, T.D. (1995). Does a general monitoring skill exist? Journal of Educational Psychology, 87, 433-444.

Schraw, G., Horn, C., Thorndike-Christ, T. \& Bruning, R. (1995). Academic goal orientations and student classroom achievement. Contemporary Educational Psychology, 20, 359-368.

Schraw,G.\&Moshman, D. (1995).Metacognitive theories. Educational Psychological Review, 7, 351-371.

Schraw, G. (1998). Promoting general metacognitive awareness. Instructional Science 26, 113-25.Swales, J. (1985).Episodes in ESP, Perganon.

Schneider, W. (1988). Review: Cognition, metacognition, and reading. Educational Researcher, 17(3), 53-5.

Schneider, W. \& Pressley, M. (1989).Memory Development Between 2 and 20. New York: Springer-Verlag.

Schunk, D.H. (1989). Self-efficacy and achievement behaviors. Educational Psychology Review, 1, 173-208.

Serpell, R. (2001). Literacy empowerment in developing societies. In Verhoeven, L \& CE Snow (Eds), Literacy and motivation. London: Lawrence Erlbaum. 222-250.

Street, B. (2001).Cultural dimensions of literacy promotion and schooling. In Verhoeven, L \& CE Snow (Eds), Literacy and motivation. London: Lawrence Erlbaum. 265-273.

Siegler, R.S. \& Jenkins, E. (1989).How Children Discover New Strategies.Hillsdale, NJ: Erlbaum.

Stern, H.H. (1975). What can we learn from the good language learner? Canadian Modern Language Review, 31, 304318.

Stern, H. (1983). Fundamental Concepts of Language Teaching. Oxford: Oxford University Press.

Verhoeven, L \& Ce Snow. (2001). Literacy and motivation. London: Lawrence Erlbaum.

Weinstein, C. E., Husman, J., \& Dierking, D. R. (2000). Self-Regulation Interventions with a Focus on Learning Strategies. Chapter 22 in the Handbook of Self-Regulation, M. Boekaerts, P.R. Pintrich \& M. Zeidner (eds.), Academic Press, p. 727-747.

Willis, J. (2009). What brain research suggests for teaching reading strategies. The Educational Forum, 73(4), 333-346.

Winne, P. H. \& Hadwin, A. F. (1998). Studying as Self-regulated learning in D.J.Hacker, J.Dunlosky, and A. Graesser (Eds) Metacognition in Educational Theory and Practice, NJ: Erlbaum.

Wistner, B \& Hideki, S \& Mariko, A. (2008). An Analysis of the Oxford Placement Test And the Michigan English Placement Test as L2 Proficiency Tests. Journal of Takasaki City, 125(50), p. 134. 